\title{
Effect of Pressurized Soy Protein Isolate upon the Growth and Antioxidants Functions of SD Rat
}

\author{
Nancy Ali1 ${ }^{1}$ Li Zhang1, Lili Li1, Laurie H. M. Chan², Baixiang Li ${ }^{*}$ \\ ${ }^{1}$ Department of Toxicology, College of Public Health, Harbin Medical University, Harbin, China \\ ${ }^{2}$ Center for Advanced Research in Environmental Genomics, University of Ottawa, Ottawa, Canada \\ Email: nancyali2000@hotmail.com, saidhabib2000@hotmail.com,
}

Received 20 February 2015; accepted 2 April 2015; published 9 April 2015

Copyright (C) 2015 by authors and Scientific Research Publishing Inc.

This work is licensed under the Creative Commons Attribution International License (CC BY).

http://creativecommons.org/licenses/by/4.0/

(c) (7) Open Access

\section{Abstract}

The objective of this study is to specify the effect of pressurized soy protein isolate (pSPI), upon the physical development, growth hormones and antioxidants functions of SD rats. The methodology depends on the selection of one hundred male SD rats, divided randomly into 5 groups. Each group consists of 20 rats. The groups will be defined as one blank control group, three groups with pSPI at low, medium and high doses and another control group with native soy protein isolates (nSPI). Low, medium and high doses are represented by $0.333 \mathrm{~g} / \mathrm{kg}, 1.667 \mathrm{~g} / \mathrm{kg}$ and 3.333 $\mathrm{g} / \mathrm{kg}$ pSPI per weight, respectively. The native soy protein isolate is represented by $3.333 \mathrm{~g} / \mathrm{kg}$ nSPI per weight. In every group, four animals will be taken out to collect the blood samples and analyze insulin like growth factor-I, growth hormone, thyroid stimulating hormone, thyroxine and triiodothyronin. The other SD rats will be subjected to feeding for 63 consecutive days. The body weight, the body length and food intake of each rat are measured. The total antioxidant capacity, superoxide dismutase (SOD), malondialdehyde and Glutathione Peroxidase in liver and serum of each rat will be analyzed. The results indicated that the groups with medium and high dose of pSPI result in an obvious increase in the body weight, body length and food utilization rate of SD rats. Also, pSPI has a great effect on the growth and antioxidants functions of SD rat.

\section{Keywords}

Pressurized Soy Protein Isolate, Triiodothyronin, Malondialdehyde, Antioxidants

\footnotetext{
${ }^{*}$ Corresponding author.
}

How to cite this paper: Ali, N., Zhang, L., Li, L.L., Chan, L.H.M. and Li, B.X. (2015) Effect of Pressurized Soy Protein Isolate upon the Growth and Antioxidants Functions of SD Rat. Food and Nutrition Sciences, 6, 501-510. 


\section{Introduction}

Protein is the material basis of life. It is the basis for growth and development. It has a dual function, not only produce energy, but also, can provide raw materials for the construction of the body's tissues, the body's growth and development. Soybeans have been an important protein source in Asian countries and have been utilized in various forms [1]. SPI is a mixture of various proteins, and the main ingredients are classified into four protein categories according to their sedimentation coefficients 2S, 7S, $11 \mathrm{~S}$ and $15 \mathrm{~S}$ which sediment at different gravitational forces when the solution is subjected to a centrifugal field [2]. Appling high pressure directly on proteins causes the formation of new bonds leading to a modified structure that presents altered functional properties as compared with native proteins [3]. For soy protein isolate not only denatured structure will be changed but also, its structure and functional properties such as, hydrated nature, the nature of the interaction between the protein and a surfactant. Also, it is more important to be able to change the biological activity [4] [5]. Soy proteins have many physiologic activities, particularly those related to the prevention of chronic diseases [6]. Anderson et al. [7] indicated that soybean contained many bioactive components such as soy protein and soy isoflavones that possess biophysiological effects. Hashizume et al. [8] studied the effect of heating temperature on conformational changes of soybean proteins. Zhang et al. [9] studied the influence of high pressure on conformational changes of soybean glycinin by means of sulphydryl group detection, spectrofluorimetry, circular dichroism, ultraviolet difference spectra, differential scanning calorimetry and electrophoresis. The results indicated that glycinin were dissociated into subunits and the conformation of these subunits had been changed after high pressure processing. Speroni et al. [10] studied the effect of high-pressure treatment on structural and rheological properties of soybean protein. From the results, high-pressure treatment, especially at $600 \mathrm{MPa}$ induced the establishment of hydrophobic interactions and disulfide bonds that allowed the formation of high molecular mass aggregates of different polypeptide composition. Song et al. [11] used high-pressure homogenization (HPH) to treat soy protein isolate (SPI) suspensions. The results showed that HPH was a facile mechanical method of reducing SPI particles size from micro to nanometer, depending on the numbers of passes through the homogenizer under certain pressures. Speroni et al. [12] analyzed the effects of calcium and high pressure treatment on the thermal properties of soybean proteins in soybean protein isolate. The antioxidant system contributed to the pathogenesis of almost all of diseases [13]. Therefore, it is great importance for either exogenous or endogenous antioxidants to scavenge the abundant free radicals to protect cellular DNA, proteins and lipid membranes. Human cells generate enzymes such as, superoxide dismutase (SOD), glutathione peroxidase (GPx), glutathione stransferase (GSH) and glutathione reductase (GR) to protect the adverse effects of free radical [14]. Orozco et al. [15] calculated the antioxidant capacity, by measuring GSH, SOD, peroxyl radical-trapping capacity (PRTC) and trolox equivalent antioxidant capacity (TEAC). Zielinska [16] evaluated the antioxidant activity of lupin sprouts were produced in the presence of two different chemical forms of selenium. Hengst et al. [17] studied the influence of the sample concentration on the measured antioxidant capacity. Zhang et al. [18] investigated the antioxidant protective effects of diet were supplemented with probiotic in hyperlipidemic Wistar rats, using an in vivo approach. The aim of the present study was to quantify the effect of pressurized soy protein isolate (pSPI), upon the physical development, growth hormones and antioxidants functions of SD rat using animal experiment.

\section{Materials and Methods}

One hundred healthy male SD rats were weaned, weighing $65 \pm 10$ g, divided randomly into 5 groups. Each group consists of 20 rats. The groups will be defined as blank control group, three groups with pSPI at low, medium and high doses (pSPI(1), pSPI(2) and pSPI(3)) and another control group with native soy protein isolates (nSPI). The recommended amount of SPI for human body is $20 \mathrm{~g} / \mathrm{d}$ in adult weight $60 \mathrm{~kg}$. It is equivalent to $0.333 \mathrm{~g} / \mathrm{kg}$ per weight. pSPI high-dose group (pSPI(3)) is selected to be 10 times of the amount recommended by the human body and equal to $3.333 \mathrm{~g} / \mathrm{kg}$ per weight per day. pSPI medium-dose group (pSPI(2)) is selected to be 5 times of the amount recommended by the human body and equal to $1.667 \mathrm{~g} / \mathrm{kg}$ per weight per day. pSPI low-dose group (pSPI(1)) is selected to be one time of the amount recommended by the human body and equal to $0.333 \mathrm{~g} / \mathrm{kg}$ per weight per day. For nSPI control group, the dose is selected to be the same as the pSPI (3) and equal to $3.333 \mathrm{~g} / \mathrm{kg}$ per weight. Sample is given by adding it to the food. Blank control group is given a direct feed on a regular basis. pSPI with low, medium and high dose group and nSPI controls group are given according to the weekly average weight calculation. Feed content of the sample is calculated according to: 


$$
\begin{aligned}
& \text { Amount added on feed sample }(\%) \\
& =\left[\text { Dose concentration }(\mathrm{g} / \mathrm{kg}) \times \text { weekly average body weight }(\mathrm{g}) \times \frac{7(\text { day })}{\text { week feed intake }(\mathrm{g})}\right] \div(10 \times 100 \%)
\end{aligned}
$$

Four animals will be taken out to collect the blood samples and analyze insulin like growth factor I (IGF-I), triiodothyronin $\left(\mathrm{T}_{3}\right)$, major of thyroid hormone in blood $\left(\mathrm{T}_{4}\right)$, thyroid stimulating hormone (TSH) and growth hormone $(\mathrm{GH})$. The blood samples will be taken in $14^{\text {th }}$ day, $49^{\text {th }}$ day, and $63^{\text {th }}$ day. The other SD rats are subjected to feeding for 63 consecutive days. The body weight, the body length and food intake for each rat are measured twice a week. After killing the rats, the blood samples are collected and the separations of the serum will be done to determine the serum growth hormone, metabolism-related hormone (IGF-I, $\mathrm{T}_{3}, \mathrm{~T}_{4}, \mathrm{TSH}$ and GH) content. Measuring the content of biochemical indicators will be done by taking the liver tissue and prepare liver tissue homogenates which are used to detect (T-AOC, SOD, MDA, GSH-Px).

\section{Statistical Analysis}

SAS statistical software is used to compare mean values from five groups by the homogeneity test. The results are expressed as means \pm standard deviation. Differences between mean values were determined by ANOVA. For all comparisons, differences with $\mathrm{P}<0.05$ were considered significant.

\section{Results and Discussions}

During the course of the experiment, all the animals are generally in a good condition, no animals have any significant adverse reactions and there is no any poisoning state or death.

\subsection{Weight Changes of SD Rats during the Experimental Period}

The total time for the experiment is 63 days. The SD rats will be orally feed at different doses, with soy protein isolate treated with high pressure. The body weight of the SD rats will be trend every week and will be compared with the control group. Table 1 shows the results of the changing of the body weights of SD rats due to the feeding in the first 7 days, 14 days, 21 days, 28 days, 35 days, 42 days, 49 days, days, 56 days and 63 days with pSPI. It indicates that, as the age increases the body weight will be increase. The pSPI (3) group and nSPI group with high dose is significantly higher than the other groups $(\mathrm{P}<0.05)$. The maximum weight is obtained in case of pSPI (3) group and equal to (407.7 g). Figure 1 shows the improvement ratio ( $\mathrm{I}_{\mathrm{R}}$ ) which can be expressed as the ratio between the different in weight at any specified time and $\left(D_{0}\right)$ to the weight at $\left(D_{0}\right)$. It shows

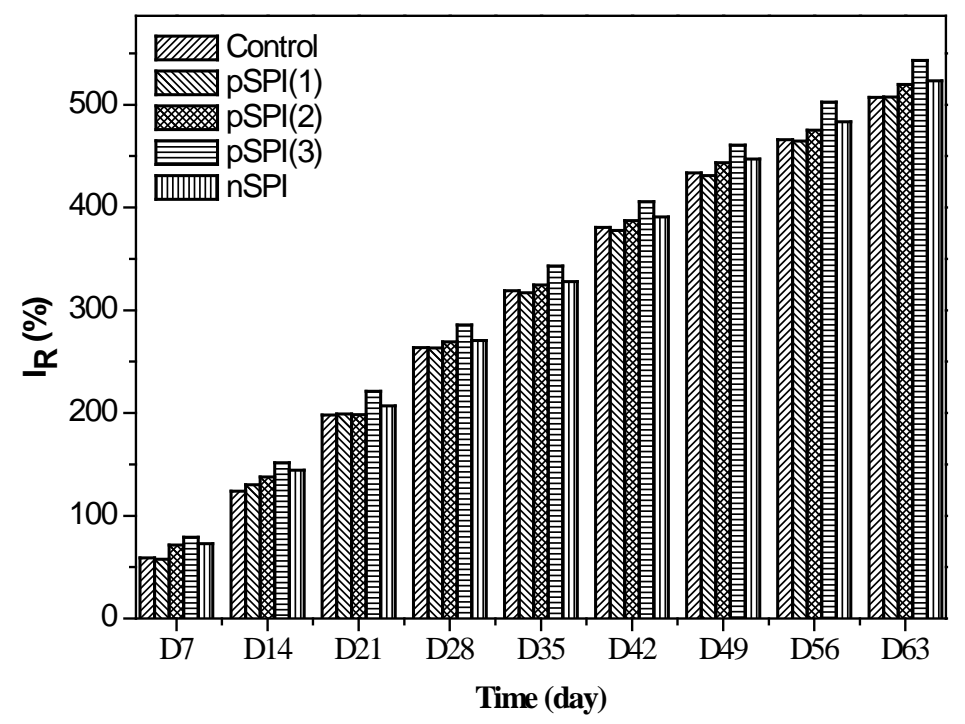

Figure 1. Improvement ratio $\left(I_{R}\right)$ due to the changing of body weight of SD rats $(n=12)$. 
Table 1. The changing of body weight of SD rats during experiment ( $\bar{X} \pm \mathrm{S}, \mathrm{n}=12$, g).

\begin{tabular}{cccccc}
\hline Group & Control & pSPI (1) & pSPI (2) & pSPI (3) & nSPI \\
\hline $\mathrm{D}_{0}$ (weight) & $63.7 \pm 9.8$ & $65.5 \pm 7.2$ & $65.0 \pm 8.8$ & $63.4 \pm 9.2$ & $64.8 \pm 8.2$ \\
$\mathrm{D}_{7}$ (weight) & $101.3 \pm 6.9$ & $103.3 \pm 9.8$ & $111.5 \pm 13.6^{*}$ & $113.6 \pm 6.2^{*}$ & $112.0 \pm 12.6^{*}$ \\
$\mathrm{D}_{14}$ (weight) & $142.6 \pm 12.6$ & $150.8 \pm 11.5$ & $154.5 \pm 14.3^{*}$ & $159.5 \pm 11.2^{*}$ & $158.3 \pm 14.1^{*}$ \\
$\mathrm{D}_{21}$ (weight) & $189.9 \pm 10.4$ & $195.8 \pm 11.3$ & $194.0 \pm 12.9$ & $203.6 \pm 8.2$ & $198.9 \pm 13.8$ \\
$\mathrm{D}_{28}$ (weight) & $231.6 \pm 9.7$ & $238.0 \pm 10.7$ & $240.0 \pm 13.1$ & $244.5 \pm 10.3$ & $240.2 \pm 8.2$ \\
$\mathrm{D}_{35}$ (weight) & $266.8 \pm 13.6$ & $273.2 \pm 16.5$ & $276.0 \pm 18.8$ & $280.9 \pm 11.7$ & $277.3 \pm 10.4$ \\
$\mathrm{D}_{42}$ (weight) & $306.1 \pm 14.6$ & $312.9 \pm 11.3$ & $316.7 \pm 10.3$ & $320.6 \pm 15.3$ & $318.1 \pm 19.3$ \\
$\mathrm{D}_{49}$ (weight) & $340.0 \pm 14.5$ & $347.7 \pm 15.2$ & $353.3 \pm 18.3$ & $355.5 \pm 17.5$ & $354.6 \pm 13.1$ \\
$\mathrm{D}_{56}$ (weight) & $360.4 \pm 16.8$ & $369.9 \pm 10.7$ & $373.8 \pm 19.6^{*}$ & $382.0 \pm 14.9^{*}$ & $378.0 \pm 15.1^{*}$ \\
$\mathrm{D}_{63}$ (weight) & $386.7 \pm 18.9$ & $397.8 \pm 12.3$ & $402.8 \pm 18.7^{*}$ & $407.7 \pm 14.5^{*}$ & $403.8 \pm 15.7^{*}$ \\
\hline
\end{tabular}

Note: ${ }^{*}$ Significantly different compared with the blank control group, $\mathrm{P}<0.05$.

that, the best $I_{R}$ is obtained in case of PSPI(3) for all measurements. The best $I_{R}$ is equals to $543 \%$ and occurs at the end of the experiment.

\subsection{The Changes in Body Length of SD Rats during the Experimental Period}

Table 2 shows the results of the changing of the body length of SD rats during the experimental period due to the feeding in the first 7 days, 14 days, 21 days, 28 days, 35 days, 42 days, 49 days, days, 56 days and 63 days with pSPI. The results indicate that, as the animals' age increase the body length will increase. pSPI(3) group and nSPI group with high dose is significantly higher than the other groups $(\mathrm{P}<0.05)$. The maximum body length is obtained in case of pSPI(3) group and equal to $(25.6 \mathrm{~cm})$. Figure 2 shows the improvement ratio (IR) which can be expressed as the ratio between the different in body length at any specified age and $\left(\mathrm{D}_{0}\right)$ to the body length at $\left(\mathrm{D}_{0}\right)$. It shows that, the best $\mathrm{I}_{\mathrm{R}}$ is obtained in case pSPI (3) and equals to $81.56 \%$.

\subsection{Effect of Soy Protein Isolates on Food Utilization in SD Rats}

Food utilization rate for animal is the increasing in body weight by a number of grams due to ingestion of each $100 \mathrm{~g}$ feed. During the feeding period the food intake of SD rats is recorded weakly to calculate the food utilization rate. Every week the rats are weighed and record the actual amount of feed intake. The food utilization rate is calculated as:

$$
\text { Food utilization rate }=\text { Weight gain }(g) / \text { Feed intake }(100 g) \times 100 \%
$$

Table 3 and Figure 3 show the effect of soy protein isolates on food utilization situation in SD rats during the experiment period. It can be shown that, the highest values of food utilization occur in the first two weeks. The lowest value of the food utilization occurs at the end of the experiment. The food utilization with high dose group was significantly higher than the control group and nSPI group. The highest value of the food utilization occurs when the SD rats fed with high dose of pSPI (pSPI (3)) and equal to (55.1\%). Also, Figure 3 shows that, as the doses of pSPI increases, the values of the food utilization will be increases. This is axiomatic due to increasing the dose.

\subsection{Effect of Soy Protein Isolates on Growth Hormones in the Blood of SD Rats}

Insulin-like growth factors I and II (IGFs) are proteins produced by the liver in response to growth hormone produced by the pituitary. IGFs are responsible for the growth and development of somatic tissues, such as skeletal muscle and bone [19]. The growth hormone (GH) and insulin-like growth factor-I (IGF-I), are an important stimulator of collagen synthesis in connective tissue. The results obtained on the 14 days, 49 days and 63 days due to the effect of soy protein isolates on IGF-I and GH, are presented in Table 4 and Table 5 . The results in- 


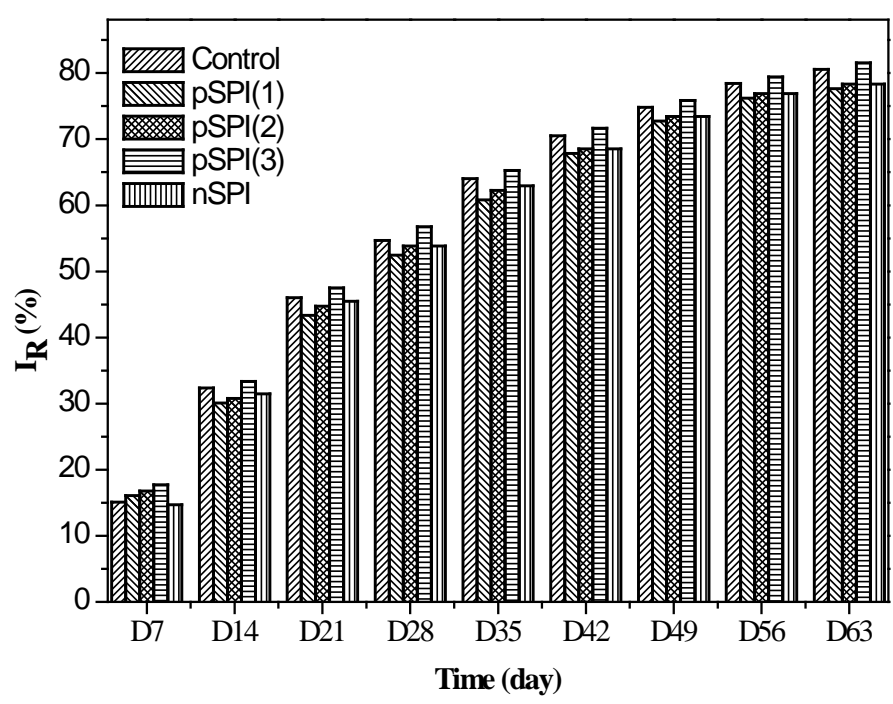

Figure 2. Improvement ratio $\left(\mathrm{I}_{\mathrm{R}}\right)$ due to changing in the body length of $\mathrm{SD}$ rats $(\mathrm{n}=12)$.

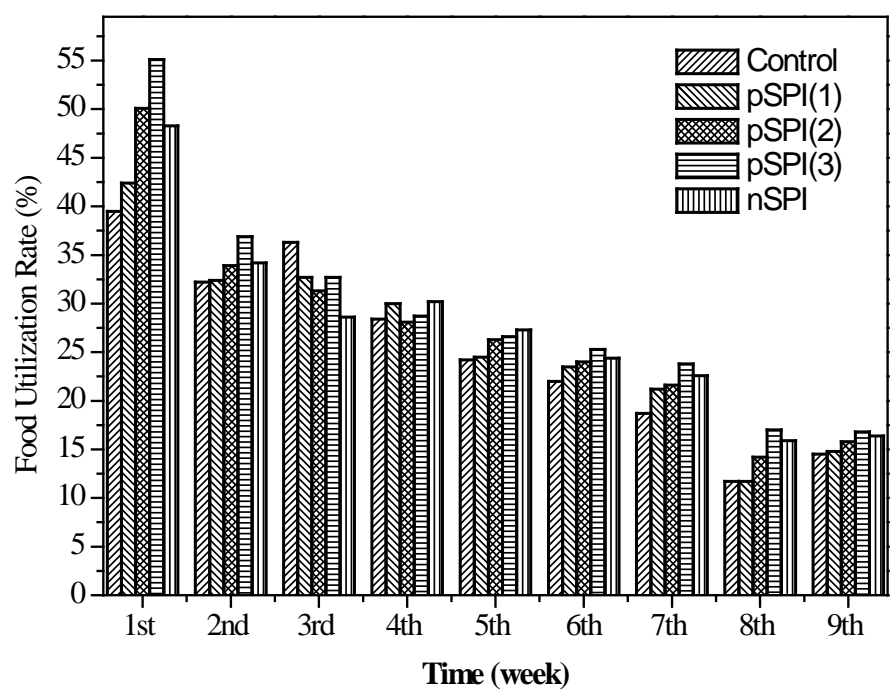

Figure 3. Effect of soy protein isolates on food utilization in SD rats.

Table 2. The changing of body length of SD rats during experiment ( $\bar{X} \pm \mathrm{S}, \mathrm{cm}, \mathrm{n}=12$ ).

\begin{tabular}{cccccc}
\hline Group & Control & pSPI (1) & pSPI (2) & pSPI (3) & nSPI \\
\hline $\mathrm{D}_{0}$ (length) & $13.9 \pm 0.6$ & $14.3 \pm 0.7$ & $14.3 \pm 0.7$ & $14.1 \pm 0.6$ & $14.3 \pm 0.7$ \\
$\mathrm{D}_{7}$ (length) & $16.0 \pm 0.4$ & $16.6 \pm 0.8$ & $16.7 \pm 0.7$ & $16.6 \pm 0.5$ & $16.4 \pm 0.8$ \\
$\mathrm{D}_{14}$ (length) & $18.4 \pm 0.5$ & $18.6 \pm 0.6$ & $18.7 \pm 0.6$ & $18.8 \pm 0.5$ & $18.8 \pm 0.6$ \\
$\mathrm{D}_{21}$ (length) & $20.3 \pm 0.3$ & $20.5 \pm 0.5$ & $20.7 \pm 0.8$ & $20.8 \pm 0.6$ & $20.8 \pm 0.7$ \\
$\mathrm{D}_{28}$ (length) & $21.5 \pm 0.3$ & $21.8 \pm 0.7$ & $22.0 \pm 0.7$ & $22.1 \pm 0.6$ & $22.0 \pm 0.5$ \\
$\mathrm{D}_{35}$ (length) & $22.8 \pm 0.3$ & $23.0 \pm 0.4$ & $23.2 \pm 0.6$ & $23.3 \pm 0.5$ & $23.3 \pm 0.6$ \\
$\mathrm{D}_{42}$ (length) & $23.7 \pm 0.4$ & $24.0 \pm 0.5$ & $24.1 \pm 0.5$ & $24.2 \pm 0.5$ & $24.1 \pm 0.7$ \\
$\mathrm{D}_{49}$ (length) & $24.3 \pm 0.4$ & $24.7 \pm 0.5$ & $24.8 \pm 0.6^{*}$ & $24.8 \pm 05^{*}$ & $24.8 \pm 0.5^{*}$ \\
$\mathrm{D}_{56}$ (length) & $24.8 \pm 0.5$ & $25.2 \pm 0.5$ & $25.3 \pm 0.5^{*}$ & $25.3 \pm 0.4^{*}$ & $25.3 \pm 0.5^{*}$ \\
$\mathrm{D}_{63}$ (length) & $25.1 \pm 0.4$ & $25.4 \pm 0.4$ & $25.5 \pm 0.3^{*}$ & $25.6 \pm 0.4^{*}$ & $25.5 \pm 0.4^{*}$
\end{tabular}

Note: *Significantly different compared with the blank control group, $\mathrm{P}<0.05$. 
Table 3. Effect of soy protein isolates on food utilization in SD rats ( $\bar{X} \pm \mathrm{S}, \%, \mathrm{n}=12$ ).

\begin{tabular}{cccccc}
\hline Group & Control & pSPI $(1)$ & pSPI (2) & pSPI (3) & nSPI \\
\hline $1^{\text {st }}$ week & $39.5 \pm 10.6$ & $42.4 \pm 14.5$ & $50.1 \pm 6.0$ & $55.1 \pm 12.6^{*}$ & $48.3 \pm 6.8$ \\
$2^{\text {nd }}$ week & $32.2 \pm 5.2$ & $32.4 \pm 5.7$ & $33.9 \pm 11.9$ & $36.9 \pm 10.0$ & $34.2 \pm 8.6$ \\
$3^{\text {rd }}$ week & $36.3 \pm 8.2$ & $32.7 \pm 11.0$ & $31.33 \pm 6.1$ & $32.7 \pm 10.5$ & $28.6 \pm 7.6$ \\
$4^{\text {th }}$ week & $28.4 \pm 6.7$ & $30.0 \pm 6.7$ & $28.1 \pm 5.1$ & $28.7 \pm 4.0$ & $30.2 \pm 10.6$ \\
$5^{\text {th }}$ week & $24.2 \pm 4.8$ & $24.5 \pm 6.3$ & $26.3 \pm 5.7$ & $26.6 \pm 7.5$ & $27.3 \pm 7.5$ \\
$6^{\text {th }}$ week & $22.0 \pm 3.2$ & $23.5 \pm 3.7$ & $24.0 \pm 4.2$ & $25.3 \pm 4.2$ & $24.4 \pm 5.0$ \\
$7^{\text {th }}$ week & $18.7 \pm 2.5$ & $21.2 \pm 3.7$ & $21.6 \pm 3.1$ & $23.8 \pm 4.3^{*}$ & $22.6 \pm 5.3$ \\
$8^{\text {th }}$ week & $11.7 \pm 3.9$ & $11.7 \pm 3.7$ & $14.2 \pm 5.1$ & $17.0 \pm 4.6^{*}$ & $15.9 \pm 4.9$ \\
$9^{\text {th }}$ week & $14.5 \pm 5.2$ & $14.8 \pm 3.6$ & $15.8 \pm 3.0$ & $16.8 \pm 4.7$ & $16.4 \pm 3.0$ \\
\hline
\end{tabular}

Note: *Significantly different compared with the blank control group, $\mathrm{P}<0.05$.

Table 4. Effect of soy protein isolates on IGF-I in the blood of SD rats ( $\bar{X} \pm \mathrm{S}, \mathrm{n}=4)$.

\begin{tabular}{cccc}
\hline & & IGF-I (ng/ml) & $\mathrm{D}_{63}$ \\
\cline { 2 - 4 } Group & $\mathrm{D}_{14}$ & $\mathrm{D}_{49}$ & $55.4 \pm 16.8$ \\
Control & $50.7 \pm 11.1$ & $49.9 \pm 5.6$ & $57.3 \pm 16.2$ \\
pSPI (1) & $51.1 \pm 15.1$ & $55.6 \pm 14.5$ & $59.6 \pm 16.0$ \\
pSPI (2) & $53.0 \pm 8.16$ & $61.0 \pm 11.0$ & $69.7 \pm 13.6$ \\
pSPI (3) & $57.9 \pm 17.9$ & $62.6 \pm 12.7$ & $58.4 \pm 10.1$ \\
nSPI & $55.6 \pm 11.1$ & $57.5 \pm 15.0$ & \\
\hline
\end{tabular}

Note: *Significantly different compared with the blank control group, $\mathrm{P}<0.05$.

Table 5. Effect of soy protein isolates on GH in the blood of SD rats $(\bar{X} \pm S n=4)$.

\begin{tabular}{cccc}
\hline Group & & GH $(\mathrm{ng} / \mathrm{ml})$ & \\
\cline { 2 - 4 } & $\mathrm{D}_{14}$ & $\mathrm{D}_{49}$ & $\mathrm{D}_{63}$ \\
\hline Control & $0.80 \pm 0.18$ & $0.65 \pm 0.08$ & $0.43 \pm 0.10$ \\
pSPI (1) & $0.82 \pm 0.22$ & $0.66 \pm 0.08$ & $0.44 \pm 0.08$ \\
pSPI (2) & $0.83 \pm 0.07$ & $0.71 \pm 0.06$ & $0.45 \pm 0.07$ \\
pSPI (3) & $0.91 \pm 0.09$ & $0.72 \pm 0.11$ & $0.51 \pm 0.07$ \\
nSPI & $0.83 \pm 0.16$ & $0.70 \pm 0.05$ & $0.45 \pm 0.06$ \\
\hline
\end{tabular}

Note: *Significantly different compared with the blank control group, $\mathrm{P}<0.05$.

dicate that, the best value of IGF-I, is occurred in case of pSPI (3) group at $\mathrm{D}_{63}$. Also, as the dose increases, the IGF-I, value will be increases. Table 5 shows the effect of soy protein isolates on GH in the blood of SD rats on the 14 days, 49 days and 63 days. It indicates that, as the age increases the value of GH decreases in all cases. The maximum value of GH is occurred with pSPI (3) group and equals to $(0.91 \mathrm{ng} / \mathrm{ml})$ at $\mathrm{D}_{14}$. The minimum value of GH is occurred with control group and equals to $(0.43 \mathrm{ng} / \mathrm{ml})$ at $\mathrm{D}_{63}$. Table 6 shows the effect of soy protein isolates on $T_{3}$ in the blood of SD rats which indicates that, as the time increases the value of $\mathrm{T}_{3}$ decreases in all cases. The maximum value of $T_{3}$ is occurred with pSPI (2) group and equals to $(0.48 \mathrm{ng} / \mathrm{ml})$ at $\mathrm{D}_{14}$. The minimum value of $\mathrm{GH}$ is occurred with control group and equals to $(0.15 \mathrm{ng} / \mathrm{ml})$ at $\mathrm{D}_{63}$. Table 7 shows the ef- 
Table 6. Effect of soy protein isolates on $\mathrm{T}_{3}$ in the blood of SD rats ( $\bar{X} \pm \mathrm{S}, \mathrm{n}=4$ ).

\begin{tabular}{cccc}
\hline Group & & $\mathrm{T} 3(\mathrm{ng} / \mathrm{ml})$ & $\mathrm{D}_{63}$ \\
\cline { 2 - 4 } & $\mathrm{D}_{14}$ & $\mathrm{D}_{49}$ & $0.15 \pm 0.04$ \\
Control & $0.42 \pm 0.09$ & $0.22 \pm 0.04$ & $0.17 \pm 0.03$ \\
pSPI (1) & $0.36 \pm 0.06$ & $0.28 \pm 0.05$ & $0.17 \pm 0.03$ \\
pSPI (2) & $0.48 \pm 0.14$ & $0.24 \pm 0.03$ & $0.18 \pm 0.02$ \\
pSPI (3) & $0.42 \pm 0.08$ & $0.29 \pm 0.03$ & $0.18 \pm 0.03$ \\
\hline
\end{tabular}

Note: *Significantly different compared with the blank control group, $\mathrm{P}<0.05$.

Table 7. Effect of soy protein isolates on $\mathrm{T}_{4}$ in the blood of SD rats $(\bar{X} \pm \mathrm{S}, \mathrm{n}=4)$.

\begin{tabular}{cccc}
\hline & & $\mathrm{T}_{4}(\mathrm{ng} / \mathrm{ml})$ & \\
\cline { 2 - 4 } Group & $\mathrm{D}_{14}$ & $\mathrm{D}_{49}$ & $\mathrm{D}_{63}$ \\
\hline Control & $40.49 \pm 3.93$ & $42.07 \pm 5.53$ & $38.16 \pm 3.00$ \\
pSPI (1) & $43.67 \pm 7.64$ & $42.45 \pm 3.85$ & $38.41 \pm 4.12$ \\
pSPI (2) & $45.29 \pm 8.92$ & $43.65 \pm 3.28$ & $39.54 \pm 3.10$ \\
pSPI (3) & $47.11 \pm 8.42$ & $43.81 \pm 7.47$ & $40.05 \pm 6.27$ \\
nSPI & $44.32 \pm 5.55$ & $43.22 \pm 8.45$ & $38.49 \pm 6.51$ \\
\hline
\end{tabular}

fect of soy protein isolates on $\mathrm{T}_{4}$ in the blood of SD rats which indicates that, the major of thyroid hormone in blood is $T_{4}$ which is too higher than $T_{3}$. Also, as the age increases the value of $T_{4}$ decreases. The maximum value of $\mathrm{T}_{4}$ is occurred with pSPI (3) group and equals to $(47.11 \mathrm{ng} / \mathrm{ml})$ at $\mathrm{D}_{14}$. The minimum value of $\mathrm{GH}$ is occurred with control group and equals to $(38.16 \mathrm{ng} / \mathrm{ml})$ at $\mathrm{D}_{63}$. Table 8 shows the effect of soy protein isolates on thyrotropin (TSH) in the blood of SD rats which indicates that, a little significant difference between all the groups but in general, as the age increases the value of TSH decreases. The maximum value of TSH is occurred with pSPI (3) group and equals to $(0.45 \mathrm{uIU} / \mathrm{ml})$ at $\mathrm{D}_{14}$. The minimum value of TSH is occurred with control group and equals to $(0.363 \mathrm{uIU} / \mathrm{ml})$ at $\mathrm{D}_{63}$.

\subsection{Effect of Soy Protein Isolates on the Total Antioxidant Capacity (T-AOC) in Blood and Liver of SD Rats}

The total antioxidant capacity (T-AOC) results due to the effect of soy protein isolates in the blood and liver of SD rats are shown in Table 9. It indicates that, the value of T-AOC content in liver, with pSPI (3) and nSPI group with high dose are significantly higher than the control group. The highest value is obtained in case of pSPI (3) group and equal to (3.41 U/mg pro) with $\mathrm{I}_{\mathrm{R}}=69.65 \%$ higher than nSPI. Also, the table shows that, the value of T-AOC content in blood is higher than the value of T-AOC content in liver and the maximum value also, occurs in case of pSPI (3) group and equal to (8.54 U/mg pro).

\subsection{Effect of Soy Protein Isolates on Malondialdehyde (MDA) Level in Blood and Liver of SD Rats}

The measured results of MDA level in the blood and liver of SD rats are shown in Table 10. The MDA level was expressed as (nmol/mg protein). The value of MDA levels with pSPI (3) and nSPI group with high dose were significantly lower than the control group $(\mathrm{P}<0.001)$. Also, the table shows that, the MDA levels in blood is higher than the value of MDA levels in liver and the maximum value occurs in case of control group and equal to $(4.27 \mathrm{nmol} / \mathrm{ml})$. With increasing the dose of pSPI groups in blood and liver the trend of MDA will be decreases. 
Table 8. Effect of soy protein isolates on TSH in the blood of SD rats ( $\bar{X} \pm \mathrm{S}, \mathrm{n}=4)$.

\begin{tabular}{cccc}
\hline \multirow{2}{*}{ Group } & & TSH (uIU/ml) & $\mathrm{D}_{63}$ \\
\cline { 2 - 4 } Control & $\mathrm{D}_{14}$ & $\mathrm{D}_{49}$ & $0.363 \pm 0.035$ \\
pSPI (1) & $0.375 \pm 0.020$ & $0.427 \pm 0.027$ & $0.380 \pm 0.048$ \\
pSPI (2) & $0.385 \pm 0.062$ & $0.373 \pm 0.023$ & $0.388 \pm 0.067$ \\
pSPI (3) & $0.423 \pm 0.034$ & $0.385 \pm 0.014$ & $0.398 \pm 0.049$ \\
nSPI & $0.450 \pm 0.029$ & $0.453 \pm 0.022$ & $0.383 \pm 0.041$ \\
\hline
\end{tabular}

Table 9. Effect of soy protein isolates on T-AOC in blood and liver of SD rats ( $\bar{X} \pm \mathrm{S}, \mathrm{n}=4)$.

\begin{tabular}{ccc}
\hline \multirow{2}{*}{ Group } & & T-AOC \\
\cline { 2 - 3 } & Liver (U/mg pro) & Blood (U/ml) \\
\hline Control & $1.55 \pm 0.35$ & $7.03 \pm 1.09$ \\
pSPI (1) & $1.80 \pm 0.45$ & $7.30 \pm 0.96$ \\
pSPI (2) & $1.84 \pm 0.42$ & $7.74 \pm 0.95^{*}$ \\
pSPI (3) & $3.41 \pm 0.52^{*}$ & $8.54 \pm 1.03^{*}$ \\
nSPI & $2.01 \pm 0.25^{*}$ & $7.98 \pm 0.82^{*}$ \\
\hline
\end{tabular}

Note: ${ }^{*}$ Significantly different compared with the blank control group, $\mathrm{P}<0.05$.

Table 10. Effect of soy protein isolates on MDA in the blood and liver of SD rats $(\bar{X} \pm \mathrm{S}, \mathrm{n}=12)$.

\begin{tabular}{ccc}
\hline \multirow{2}{*}{ Group } & & MDA \\
\cline { 2 - 3 } & Liver (nmol/mg pro) & Blood (nmol/ml) \\
\hline Control & $0.63 \pm 0.11$ & $4.27 \pm 0.74$ \\
pSPI (1) & $0.42 \pm 0.08$ & $3.90 \pm 0.48$ \\
pSPI (2) & $0.41 \pm 0.09$ & $3.71 \pm 0.44^{*}$ \\
pSPI (3) & $0.24 \pm 0.08^{*}$ & $3.48 \pm 0.39^{*}$ \\
nSPI & $0.29 \pm 0.07^{*}$ & $3.71 \pm 0.50^{*}$ \\
\hline
\end{tabular}

Note: ${ }^{*}$ Significantly different compared with the blank control group, $\mathrm{P}<0.05$.

\subsection{Effect of Soy Protein Isolates on Super Oxide Dismutase (SOD) in Blood and Liver of SD Rats}

SOD is an important antioxidant enzyme in organisms and also a natural scavenger of superoxide anion. SOD catalysis superoxide anion $\left(\mathrm{O}_{2}^{-}\right)$to generate $\mathrm{H}_{2} \mathrm{O}_{2}$, this clears $\left(\mathrm{O}_{2}^{-}\right.$) toxic effects on cells. The measured results of SOD in the blood and liver of SD rats are shown in Table 11. It indicates that, the value of SOD in liver, with pSPI (3) and nSPI group with high dose are significantly higher than the control group $(\mathrm{P}<0.05)$. The highest value is obtained in case of pSPI (3) group and equal to ( $353.5 \mathrm{U} / \mathrm{mg}$ pro) with $\mathrm{I}_{\mathrm{R}}=5.43 \%$ higher than nSPI. Also, the table shows that, the value of SOD in liver is higher than the value of SOD content in blood.

\subsection{Effect of Soy Protein Isolates on Glutathione Peroxidase (GSH-Px) in Blood and Liver of SD Rats}

GSH-Px is an $80 \mathrm{kDa}$ protein composed of four identical sub-units. Five isoforms of GSH-Px are well characterized in mammals and show tissue-specific distribution. Alteration of these enzyme levels is associated with diverse cancer types, including skin, kidney, intestine and breast cancer [20]. The GSH-Px activities is measured by its ability to utilize the standard GSH in the presence of specific amount of hydrogen peroxide, which can be determined by the decrease of the GSH levels at $412 \mathrm{~nm}$. The measured results of Glutathione peroxidase (GSHPx) in the blood and liver of SD rats are shown in Table 12. It indicates that, the value of GSH-Px in liver, 
Table 11. Effect of soy protein isolates on SOD in the blood and liver of SD rats ( $\bar{X} \pm \mathrm{S}, \mathrm{n}=12$ ).

\begin{tabular}{ccc}
\hline & & SOD \\
\cline { 2 - 3 } Group & Liver (U/mg pro) & Blood (U/ml) \\
\hline Control & $327.7 \pm 15.9$ & $102.1 \pm 8.1$ \\
pSPI (1) & $337.6 \pm 17.5$ & $103.3 \pm 6.8$ \\
pSPI (2) & $344.9 \pm 20.6^{*}$ & $109.6 \pm 8.5^{*}$ \\
pSPI (3) & $353.5 \pm 14.5^{*}$ & $111.5 \pm 7.7^{*}$ \\
nSPI & $335.3 \pm 14.5^{*}$ & $110.8 \pm 9.5^{*}$ \\
\hline
\end{tabular}

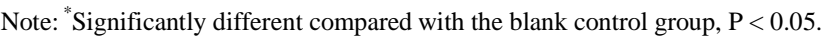

Table 12. Effect of soy protein isolates on GSH-Px in liver of SD rats ( $\bar{X} \pm \mathrm{S}, \mathrm{n}=12$ ).

\begin{tabular}{ccc}
\hline & & GSH-Px activities \\
\hline Group & Liver (U/mg pro) & Blood (U/ml) \\
\cline { 2 - 3 } & $1037 \pm 110$ & $872 \pm 69$ \\
pSPI (1) & $1088 \pm 117$ & $895 \pm 59$ \\
pSPI (2) & $1121 \pm 71$ & $899 \pm 75$ \\
pSPI (3) & $1196 \pm 98^{*}$ & $971 \pm 85^{*}$ \\
nSPI & $1154 \pm 94^{*}$ & $954 \pm 86^{*}$ \\
\hline
\end{tabular}

Note: *Significantly different compared with the blank control group, $\mathrm{P}<0.05$.

at pSPI (3) and nSPI group with high dose are significantly higher than the control group. The highest value is obtained in case of pSPI (3) group and equal to (1196 U/mg pro) with $\mathrm{I}_{\mathrm{R}}=3.64 \%$ higher than nSPI. Also, the table shows that, the value of GSH-Px in liver is higher than the value of GSH-Px content in blood.

\section{Conclusion}

The effect of pressurized soy protein isolate (pSPI) upon the physical development, growth hormones and antioxidants functions of SD rats using animal experiment is studied. The results show that the groups with medium and high dose of pSPI result in an obvious increase in the body weight, body length and food utilization rate of rats. The highest values of food utilization occur in the first two weeks. The lowest values of the food utilization occur at the end of the experiment. In the pSPI high dose group and nSPI control group, the MDA content decreases and the activity of total antioxidant capacity (T-AOC) and glutathione peroxidase (GSH-PX) in liver is raised significantly ( $\mathrm{P}<0.05$ ), compared with that of blank group. In the pSPI high, medium dose group and nSPI control group, the MDA content decreases and the activity of T-AOC and superoxide dismutase (SOD) in serum is raised significantly $(\mathrm{P}<0.05)$, compared with that of blank group also, SOD in liver. Total antioxidant capacity (T-AOC) is an important indicator, which directly reflects the body activity and the overall level of non-enzymatic antioxidants. It is also a way to reflect the body's antioxidant status. Studies in rats show that a certain amount of pSPI can enhance defense system in animals and maintain the body's health in good state.

\section{Acknowledgements}

This work is supported by the Ministry of Science and Technology of China. The grant number is 2007DFA30820.

\section{References}

[1] Nishinari, K. (1988) Food hydrocolloids in Japan. National Food Research Institute, Tsukuba.

[2] Peng, I.C., Quass, D.W., Dayton, W.R. and Allen, C.E. (1984) Physicochemical and Functional Properties of Soybean 11S Globulin-A Review. Cereal Chemistry, 61, 480-490. 
[3] Molina, E., Papadopoulou, A. and Ledward, D.A. (2001) Emulsifying Properties of High Pressure Treated Soy Protein Isolate and 7S and 11S Globulins. Food Hydrocolloids, 15, 263-269. http://dx.doi.org/10.1016/S0268-005X(01)00023-6

[4] Puppo, C. and Chapleau, N. (2004) Physicochemical Modifications of High-Pressure-Treated Soybean Protein Isolates. Food Chemistry, 52, 1564-1571. http://dx.doi.org/10.1021/jf034813t

[5] Takenaka, A. and Annaka, H. (2003) Reduction of Paraquat-Induced Pxidative Stress in Rat by Dietary Soy Peptide. Bioscience Biotechnology and Biochemistry, 67, 278-283. http://dx.doi.org/10.1271/bbb.67.278

[6] Wu, W., Zhang, C. and Hua, Y. (2009) Structural Modification of Soy Protein by the Lipid Peroxidation Product Malondialdehyde. Journal of the Science of Food and Agriculture, 89, 1416-1423. http://dx.doi.org/10.1002/jsfa.3606

[7] Anderson, J., Johnstone, B. and Cook-Newell, M. (1995) Meta-Analysis of the Effects of Soy Protein Intake on Serum Lipids. England Journal of Medicine, 333, 276-282. http://dx.doi.org/10.1056/NEJM199508033330502

[8] Hashizume, K. and Watababe, T. (1979) Influence of Heating Temperature on Conformational Changes of Soybean Proteins. Agricultural and Biological Chemistry, 43, 683-690. http://dx.doi.org/10.1271/bbb1961.43.683

[9] Zhang, H., Li, L., Tatsumi, E. and Kotwal, S. (2003) Influence of High Pressure on Conformational Changes of Soybean Glycinin. Innovative Food Science and Emerging Technologies, 4, 269-275. http://dx.doi.org/10.1016/S1466-8564(03)00043-2

[10] Speroni, F., Beaumal, V., Lamballerie, Md., Anton, M., Anona, M.C. and Puppo, M.C. (2009) Gelation of Soybean Proteins Induced by Sequential High-Pressure and Thermal Treatments. Food Hydrocolloids, 23, 1433-1442. http://dx.doi.org/10.1016/j.foodhyd.2008.11.008

[11] Song, X., Zhoub, C., Fuc, F., Chenc, Z. and Wub, Q. (2013) Effect of High-Pressure Homogenization on Particle Size and Film Properties of Soy Protein Isolate. Industrial Crops and Products, 43, 538-544. http://dx.doi.org/10.1016/j.indcrop.2012.08.005

[12] Speroni, F., Añón, M.C. and Lamballerie, M.D. (2010) Effects of Calcium and High Pressure on Soybean Proteins: A Calorimetric Study. Food Research International, 43, 1347-1355. http://dx.doi.org/10.1016/j.foodres.2010.03.022

[13] Gupta, S., Hevia, D., Patchva, S., Park, B., Koh, W. and Aggarwal, B. (2012) Upsides and Downsides of Reactive Oxygen Species for Cancer: The Roles of Reactive Oxygen Species in Tumorigenesis, Prevention, and Therapy. Antioxidants \& Redox Signaling, 16, 1295-1322. http://dx.doi.org/10.1089/ars.2011.4414

[14] Turrens, J. (2003) Mitochondrial Formation of Reactive Oxygen Species. Journal of Physiology, 552, 335-344. http://dx.doi.org/10.1113/jphysiol.2003.049478

[15] Orozco, R.F., Piskula, M.K., Zielinski, H., Kozlowska, H., Frias, J. and Vidal-Valverde, C. (2006) Germination as a Process to Improve the Antioxidant Capacity of Lupinus angustifolius L. var. Zapaton. European Food Research and Technology, 223, 495-502. http://dx.doi.org/10.1007/s00217-005-0229-1

[16] Zielinska, D., Frias, J., Piskuła, M.K., Kozłowska, H., Zielinsk, H. and Vidal-Valverde, C. (2008) Evaluation of the Antioxidant Capacity of Lupin Sprouts Germinated in the Presence of Selenium. European Food Research and Technology, 227, 1711-1720. http://dx.doi.org/10.1007/s00217-008-0898-7

[17] Hengst, C., Werner, S., Müller, L., Fröhlich, K. and Böhm, V. (2009) Determination of the Antioxidant Capacity: Influence of the Sample Concentration on the Measured Values. European Food Research and Technology, 230, 249-254. http://dx.doi.org/10.1007/s00217-009-1166-1

[18] Zhang, Y., Du, R., Wang, L. and Zhang, H. (2010) The Antioxidative Effects of Probiotic Lactobacillus casei Zhang on the Hyperlipidemic Rats. European Food Research and Technology, 231, 151-158.

[19] Maki, R.G. (2010) Small Is Beautiful: Insulin-Like Growth Factors and Their Role in Growth, Development, and Cancer. Journal of Clinical Oncology, 28, 4985-4995. http://dx.doi.org/10.1200/JCO.2009.27.5040

[20] Townsend, D. and Tew, K. (2003) The Role of Glutathione-S-Transferase in Anti-Cancer Drug Resistance. Oncogene, 22, 7369-7375. http://dx.doi.org/10.1038/sj.onc.1206940 